Kredo 4 (2020)
KREDO: Jurnal Ilmiah Bahasa dan Sastra
Terakreditasi Sinta 4 berdasarkan Keputusan Direktorat
Jenderal Penguatan Riset dan Pengembangan,
Kementerian Riset, Teknologi dan Pendidikan Tinggi
Republik Indonesia
Nomor: 23/E/KPT/2019. 08 Agustus 2019
https://jurnal.umk.ac.id/index.php/kredo/index

\title{
PENGARUH PENGGUNAAN MODEL RALLY COACH TERHADAP KETERAMPILAN BERBICARA BAHASA INGGRIS MAHASISWA STMIK PRANATA CILEUNGSI
}

\author{
Doni Anggoro Ari Santoso ${ }^{1}$, Agung Prasetyo ${ }^{2}$, Zumrotul Muniroh ${ }^{3}$ \\ don.okba@gmail.com
}

Universitas Indraprasta PGRI, Indonesia

\begin{abstract}
Info Artikel
Sejarah Artikel

Diterima

7 Februari 2020

Disetujui

21 September 2020

Dipublikasikan

28 Oktober 2020
\end{abstract}

Keywords

rally coach model,

speaking skill

Kata Kunci

keterampilan berbicara, model pembelajaran, rally coach
:

: learning aims to keep students focused on what they are learning as a whole, especially speaking skill. English learning target in higher education is to make students able to speak English fluently. Lack of confidence and learning method used by the lecturer are the problems that students have in learning process. Lecturers should be able to use various and effective medias, methods, or learning models that can help students learning English in interesting way to reach the target of learning. The aim of this research is to find out the effect of Rally Coach model towards students' speaking skiil of STMIK Pranata, Cileungsi. This research used experiment design of quantitative method with two groups of students. The reasearch result shows that $t_{\text {count }}$ score is 1,69 and table : $\quad$ score is 1,667. The score of $t_{\text {count }}$ is more than $t_{\text {table; }}$; so it can be concluded that there is positive and significant effect of using Rally Coach model towards students' speaking skill of STMIK Pranata, Cileungsi. Pembelajaran yang aktif bertujuan untuk menjaga mahasiswa untuk tetap fokus terhadap apa yang sedang mereka pelajari secara keseluruhan, khususnya keterampilan berbicara. Pada tingkat perguruan tinggi, target pembelajaran bahasa Inggris adalah mahasiswa mampu menggunakan bahasa Inggris lisan dengan baik dan lancar. Kurangnya percaya diri dan kurangnya variasi dalam penggunaan metode pembelajaran menjadi permasalahan yang dihadapi oleh mahasiswa. Dalam mempelajari keterampilan berbicara, pendidik dituntut untuk mampu menggunakan media, metode atau model pembelajaran yang efektif dan menarik agar mahasiswa dapat fokus, lebih percaya diri, dan tidak bosan dengan tidak menghilangkan tujuan utama dari apa yang sedang dipelajari. Tujuan dari penelitian ini adalah untuk mengetahui pengaruh model pembelajaran Rally Coach terhadap keterampilan berbicara bahasa Inggris mahasiswa STMIK Pranata, Cileungsi. Metode yang digunakan dalam penelitian ini adalah metode kuantitatif dengan desain eksperimen dengan dua kelompok siswa. Hasil dari penelitian menunjukkan nilai $t_{\text {hitung }}$ sebesar 1,69 dan lebih besar dari nilai $\mathrm{t}_{\text {tabel }}$ sebesar 1,667. Maka dapat disimpulkan bahwa terdapat pengaruh yang positif dan signifikan penggunaan model pembelajaran Rally Coach terhadap keterampilan berbicara bahasa Inggris mahasiswa STMIK Pranata, Cileungsi.

\section{PENDAHULUAN}

Untuk membentuk sumber daya manusia yang berkualitas pada suatu Negara, maka dibutuhkan sebuah sistem Pendidikan yang baik. Dalam pelaksanaan pendidikan selalu dibutuhkan perbaikan secara berkelanjutan sehingga terbentuk sistem yang baik. Pendidikan merupakan suatu hal yang penting dalam membentuk kehidupan yang cerdas, dinamis, dan demokratis. Upaya yang dilakukan untuk membentuk kehidupan yang cerdas, maka perlu dilakukan peningkatan kualitas pendidikan nasional dengan cara memperbaharui sistem pendidikan. Banyak hal telah dilakukan seperti memperbaharui kurikulum, peningkatan 


Kredo 4 (2020)
KREDO: Jurnal Ilmiah Bahasa dan Sastra
Terakreditasi Sinta 4 berdasarkan Keputusan Direktorat
Jenderal Penguatan Riset dan Pengembangan,
Kementerian Riset, Teknologi dan Pendidikan Tinggi
Republik Indonesia
Nomor: 23/E/KPT/2019. 08 Agustus 2019
https://jurnal.umk.ac.id/index.php/kredo/index

kualitas tenaga pengajar, penyedian perpustakaan, penyediaan laborartorium, penataan manajemen pendidikan, dan penerapan produk teknologi dalam pendidikan.

Pembelajaran yang aktif (active learning) adalah sebuah pembelajaran yang menjadi sebuah tujuan dari pendidikan nasional, hal ini dimaksudkan agar perhatian siswa tetap terjaga dan tertuju pada proses pembelajaran secara keseluruhan. Pembelajaran aktif yang seperti ini, hanya dapat dirasakan ketika pengajar mampu menggunakan berbagai metode, model pembelajaran, dan media yang baik dan menarik, hal tersebut dilakukan agar proses pembelajaran berlangsung dengan fokus, menyenangkan, dan tidak membosankan, dan target pembelajaran tercapai dengan baik.

Bahasa Inggris memegang peranan penting sebagai bahasa pergaulan internasional. Bahasa Inggris dipelajari secara formal di Indonesia mulai dari TK sampai dengan Perguruan Tinggi. Untuk TK Grup B, tingkat pencapaian perkembangan untuk pembelajaran bahasa Inggris adalah anak memiliki keterampilan mendengarkan dan berbicara praktis dan sederhana dalam bahasa Inggris dalam tema yang diajarkan (Maulidiyah, 2014: 8). Kemudian, adapun tujuan pengajaran Bahasa Inggris di SD/MI berdasarkan peraturan Menteri Pendidikan Nasional RI No. 22 tahun 2006 tanggal 23 Mei 2006 adalah untuk mengembangkan kompetensi berkomunikasi dalam bentuk lisan secara terbatas untuk mengiringi tindakan (Language accompanying action) dalam konteks sekolah serta memiliki kesadaran tentang hakikat dan pentingnya Bahasa Inggris untuk meningkatkan daya saing bangsa dalam masyarakat global (Farikah, 2016).

Selanjutnya, pada tingkat SMP, tujuan pelajaran bahasa Inggris adalah untuk mengembangkan kemampuan berkomunikasi dalam bentuk lisan dan tulis (Boediono, 2003: 14). Berikutnya, tujuan pembelajaran bahasa Inggris pada tingkat SMA adalah untuk menghasilkan peserta didik yang mampu menggunakan bahasa Inggris secara performatif, fungsional, dan epistemik (Rachmawati dan Madya, 2014). Tujuan pembelajaran bahasa Inggris dalam konteks ESP (English for Spesific Purposes) di perguruan tinggi adalah agar mahasiswa mampu menggunakan bahasa Inggris baik secara tertulis maupun lisan dalam memahami bacaan dalam teks berbahasa Inggris khusus jurusan di masing-masing fakultas (Wardah, 2017).

Kurikulum pendidikan bahasa Inggris terus di-update sesuai perkembangan zaman. Salah satu upaya yang dimaksud adalah pemanfaatan teknik pembelajaran dalam proses belajar mengajar. Dikarenakan pemanfaatan teknik pembelajaran dapat mempertinggi kualitas proses belajar mengajar yang pada akhirnya dapat meningkatkan kualitas hasil belajar mahasiswa.

Sebuah keharusan dan tuntutan bagi setiap tenaga pengajar untuk mampu menyelenggarakan proses pembelajaran dengan menggunakan berbagai metode pembelajaran, model pembelajaran, dan media untuk mencapai tujuan pendidikan. Kemampuan setiap pendidik untuk menggunakan berbagai macam media, model pembelajaran, dan metode pembelajaran yang cocok dan sesuai 


Kredo 4 (2020)
KREDO: Jurnal Ilmiah Bahasa dan Sastra
Terakreditasi Sinta 4 berdasarkan Keputusan Direktorat
Jenderal Penguatan Riset dan Pengembangan,
Kementerian Riset, Teknologi dan Pendidikan Tinggi
Republik Indonesia
Nomor: 23/E/KPT/2019. 08 Agustus 2019
https://jurnal.umk.ac.id/index.php/kredo/index

juga harus diperhatikan. Hal ini menjadi harapan bahwa untuk menciptakan suasana pembelajaran yang menarik dan menyenangkan, kretaifitas tenaga pengajar sangatlah dibutuhkan.

Pembelajaran bahasa Inggris pada tingkat pendidikan tinggi merupakan penanaman ilmu pengetahuan yang mendasar untuk membantu mahasiswa untuk memahami bahasa Inggris dari segi makna dan fungsi. Memiliki kemampuan bahasa Inggris dapat meningkatkan kemampuan intelektual, kematangan ekonomi dan kematangan sosial serta memiliki disiplin dalam berpikir dan berbahasa.

Dalam pembelajaran bahasa Inggris, masih terdapat siswa yang belum mampu memahami bacaan teks sesuai dengan struktur/pola kalimat. Hal tersebut diperkuat dengan dirilisnya hasil laporan PISA 2018 yang memaparkan hasil kemampuan membaca siswa Indonesia yang berada pada peringkat 74 , dengan rata-rata skor 371 (Permana, 2019). Selain membaca, mahasiswa juga harus mampu menyimak, berbicara, menulis, pragmatik, dan tata bahasa (grammar). Keberhasilan proses belajar mengajar tersebut dipengaruhi oleh teknik mengajar bahasa yang dilaksanakan oleh pengajar.

Terdapat 4 (empat) keterampilan dalam Bahasa Inggris yang harus dimiliki mahasiswa yaitu menyimak, berbicara, membaca dan menulis (listening, speaking, reading and writing). Di samping kemampuan menyimak, berbicara, membaca dan menulis mahasiswa juga harus menguasai tata bahasa (grammar). Namun pada kenyataannya, masih terdapat mahasiswa STMIK Pranata mendapat kesulitan memahaminya. Hal tersebut terlihat pada saat peneliti melakukan observasi dan dibuktikan kembali pada nilai kelas kontrol yang hanya mendapat rata-rata nilai 64,7. Nilai yang rendah tersebut dikarenakan kesulitan yang dialami mahasiswa dalam menguasai tata bahasa Inggris dan membuat mereka kesulitan dalam berbicara dan menyusun kalimat yang dapat dimengerti oleh lawan bicaranya.

Salah satu keterampilan bahasa Inggris yang berkaitan dengan penelitian yang dilaksanakan oleh peneliti adalah keterampilan berbicara. Pada tahap observasi, peneliti masih menemukan beberapa mahasiswa di STMIK Pranata mengalami kesulitan pada saat diminta untuk berbicara dalam bahasa Inggris. Mereka kesulitan dalam menyesuaikan kata kerja dalam tata bahasa Inggris yang digunakan. Hal ini disebabkan karena mata kuliah bahasa Inggris dipelajari rata-rata hanya 2 sks, dengan waktu belajar yang hanya seminggu 1 kali pertemuan, oleh sebab itu dirasa cukup sulit bagi mahasiswa untuk dapat memahami bahasa Inggris. Selain itu, pembelajaran yang monoton juga menjadi penyebab sulitnya mahasiswa menguasai bahasa Inggris. Dampak dari hal tersebut adalah rendahnya rata-rata nilai keterampilan berbicara dari kelas kontrol yang hanya 64,7.

Berkaitan dengan latar belakang diatas, peneliti melaksanakan penelitian dengan mengunakan model pembelajaran kooperatif Rally Coach dalam upaya peningkatan hasil belajar dan keterampilan berbicara dalam bahasa Inggris. Dengan adanya teknik pembelajaran tersebut diharapkan mahasiswa mampu lebih aktif dan 


Kredo 4 (2020)
KREDO: Jurnal Ilmiah Bahasa dan Sastra
Terakreditasi Sinta 4 berdasarkan Keputusan Direktorat
Jenderal Penguatan Riset dan Pengembangan,
Kementerian Riset, Teknologi dan Pendidikan Tinggi
Republik Indonesia
Nomor: 23/E/KPT/2019. 08 Agustus 2019
https://jurnal.umk.ac.id/index.php/kredo/index

tertarik dalam pelajaran bahasa Inggris khususnya dalam meningkatkan ketrampilan berbicara. Karena dalam teknik tersebut mahasiswa berkaitan langsung secara pasangan atau kelompok dengan lawan bicara, yaitu temannya sendiri, sehingga mahasiswa tidak merasa takut atau kurang rasa percaya diri jika mengalami kesalahan.

Tujuan dari penelitian ini adalah untuk mengetahui apakah pembelajaran kooperatif model Rally Coach dapat mempengaruhi hasil belajar berbicara bahasa Inggris STMIK Pranata, Cileungsi. Dan hasil dari penelitian ini diharapkan dapat menjadi solusi dalam pembelajaran bahasa Inggris khususnya keterampilan berbicara.

Penelitian ini diharapkan dapat menjadi solusi dalam pembelajaran bahasa Inggris pada mahasiswa. Penggunaannya yang melibatkan antar sesama mahasiswa di dalam kelas diharapkan dapat membuat mereka lebih aktif dan percaya diri dalam proses pembelajaran bahasa Inggris khususnya keterampilan berbicara bahasa Inggris.

\section{KAJAN TEORI}

\section{a. Bahasa Inggris}

Bahasa Inggris adalah sebuah bahasa yang digunakan di beberapa Negara selain Amerika dan Inggris sebagai media komunikasi utama. Sebagai media komunikasi utama, untuk berinteraksi dengan banyak orang di seluruh dunia seseorang membutuhkan Bahasa Inggris dalam kehidupan seharihari.

Hal yang sama dengan pendapat Hornby (2006: 486) yang berpendapat bahasa Inggris saat ini digunakan oleh banyak negara di dunia dan digunakan sebagai bahasa Internasional untuk berkomunikasi dengan banyak orang di dunia. Oleh sebab itu, sangatlah penting bagi setiap orang untuk mempelajari bahasa Inggris, karena sangatlah mudah bagi kita untuk berkomunikasi, bertukar kabar maupun pesan dengan orang-orang yang berasal dari Negara yang berbeda dengan menggunakan bahasa Inggris baik ketika kita berada di dalam negeri ataupun ketika kita berada di luar negeri.

Perlunya penguasaan bahasa Inggris sebagai bahasa pergaulan internasional, maka siswa diwajibkan untuk mempelajari bahasa Inggris secara formal sampai dengan Perguruan Tinggi. Dalam mencapai tujuan pembelajaran, maka kurikulum pendidikan bahasa Inggris perlu diperbaharui sesuai dengan perkembangan zaman. Salah satu upaya yang dimaksud adalah pemanfaatan teknik pembelajaran dalam proses belajar mengajar. Karena pemanfaatan teknik pembelajaran dapat mempertinggi kualitas proses belajar mengajar yang pada akhirnya dapat meningkatkan kualitas hasil belajar mahasiswa.

\section{b. Pembelajaran Bahasa Inggris}

Pembelajaran adalah sebuah usaha yang dilakukan dengan sengaja yang melibatkan dan menggunakan pengetahuan, profesionalisme yang dimiliki oleh guru untuk mencapai tujuan dari kurikulum atau dengan kata lain pembelajaran adalah suatu aktifitas yang dilakukan dengan sengaja, memodifikasi berbagai kondisi yang diarahkan untuk tercapainya suatu tujuan, yaitu tujuan kurikulum (Dimyati dan Mudjiono, 2006: 3).

\section{6 | Jurnal Kredo \\ Vol. 4 No. 1 Oktober 2020}




Kredo 4 (2020)
KREDO: Jurnal Ilmiah Bahasa dan Sastra
Terakreditasi Sinta 4 berdasarkan Keputusan Direktorat
Jenderal Penguatan Riset dan Pengembangan,
Kementerian Riset, Teknologi dan Pendidikan Tinggi
Republik Indonesia
Nomor: 23/E/KPT/2019. 08 Agustus 2019
https://jurnal.umk.ac.id/index.php/kredo/index

Dalam pembelajaran bahasa Inggris, setiap pengajar harus memperhatikan bahwa dalam pengajaran bahasa Inggris, setiap tenaga pengajar perlu memiliki tujuan pengajaran bahasa yang unik dan menarik. Dalam mengajar bahasa Inggris sebagai bahasa Internasional, tenaga pengajar harus mampu menggunakan pendekatan belajar yang baik dan sesuai untuk mencapai tujuan pembelajaran (McKay, dkk., 2009:1).

Pendapat tersebut juga dikemukakan oleh Celce (2001: 8) yang menyatakan bahwa sebagai bahasa Internasional, bahasa Inggris akan digunakan oleh siswa, mahasiswa, atau masyarakat dalam berkomunikasi dalam mengikuti perkembangan zaman. Oleh sebab itu, perlu adanya peningkatan pembelajaran yang dimulai dari tingkat dasar hingga perguruan tinggi dalam pembelajaran bahasa Inggris.

Dalam berbahasa, juga terdapat aturan-aturan yang harus dipahami karena tanpa aturan, maka akan terjadi komunikasi yang tidak efektif dan tidak berjalan dengan lancar, bahkan akan terjadi kesalahpahaman diantara mereka. Maka dari itu, agar dapat berkomunikasi dengan baik, pendidik juga harus mengajarkan aturan-aturan bahasa yang digunakan dalam bahasa Inggris. Hal tersebut sebagaimana dikemukakan oleh Siahaan (2008:1) yaitu: "Language is a set of rules and used by human as a tool of their communication". Kutipan tersebut memiliki arti bahwa untuk berkomunikasi dengan baik, orang yang berkomunikasi harus menggunakan aturan-aturan bahasa yang baik agar dapat dipahami.

Uraian di atas juga senada dengan yang dikemukakan oleh Richards \&
Renandya (2002:84) "Language is functional and must be contextualized because of the purpose we put it does". Maksud dari kutipan tersebut adalah penyampaian materi-materi ketatabahasaan harus sesuai dengan konteks bahasa yang digunakan pada saat ini. Tanpa pengetahuan akan bahasa yang digunakan sekarang ini, maka seseorang dan lingkungan sosialnya tidak mungkin memahami arti atau maksud yang sesungguhnya yang terjadi dalam interaksi sehari-hari.

Namun, banyak anggapan bahwa sangatlah sulit untuk menguasai bahasa Inggris. Hal ini disebabkan karena penggunaan Bahasa Inggris baik secara lisan ataupun tulisan yang terlalu mementingkan dan menekankan pada ketepatan penggunaan, dan aturan bahasa atau struktur (Grammar). Untuk dapat menguasai bahasa Inggris, pembelajar dituntut untuk mempelajari dan menguasai unsur-unsur yang ada dalam bahasa Inggris. Pembelajar wajib mempelajari pengucapan, menguasai kosakata, dan struktur atau tata bahasa dalam bahasa Inggris.

Sangatlah penting bagi setiap siswa untuk menguasai bahasa Inggris karena dengan menguasainya akan dapat dengan mudah untuk berkomunikasi dengan banyak orang dari berbagai negara. Dengan menguasai bahasa Inggris sebagai bahasa Internasional, berkomunikasi, berinteraksi, dan bertukar kabar dengan masyarakat dari negara lain bukanlah hal yang menyulitkan.

Sangat penting bagi para guru untuk mengetahui perbedaan latar belakang, pengalaman, gaya belajar mahasiswa untuk kemudian mempraktikkan bahasa 


\begin{tabular}{|c|c|c|} 
Kredo 4 (2020) \\
KREDO: Jurnal Ilmiah Bahasa dan Sastra \\
Terakreditasi Sinta 4 berdasarkan Keputusan Direktorat \\
Jenderal Penguatan Riset dan Pengembangan, \\
Kementerian Riset, Teknologi dan Pendidikan Tinggi \\
Republik Indonesia \\
Nomor: 23/E/KPT/2019. 08 Agustus 2019 \\
https://jurnal.umk.ac.id/index.php/kredo/index
\end{tabular}

di dalam kelas. Karena mempelajari bahasa merupakan proses pembelajaran individu sesuai dengan informasi yang didapat memalui sistem bahasa yang digunakan dalam kehidupan sehari-hari. Hal tersebut sesuai dengan pendapat Richard \& Renandya (2002:87): "Although language is a social practice, learning language is a largely an individual process as learners seek to integrate newly perceived information into their existing language system".

Belajar bahasa bukanlah sekedar menguasai aturan bahasa dan menguasai kosakata yang banyak. Para pengajar seharusnya tidak hanya mentransfer informasi kepada mahasiswanya tentang bahasa tetapi juga mempraktikkan bahasa yang sudah dipelajari.

Pada dasarnya bahasa digunakan sebagai alat komunikasi untuk menyampaikan ide atau gagasan atau apapun kepada orang yang satu ke orang yang lain. Dan merupakan aspek yang sangat fundamental sebagai alat berekspresi dan berkomunikasi dengan orang lain. Tidak ada bahasa maka manusia tidak dapat mengutarakan keinginannya kepada orang lain.

\section{c. Hasil Belajar}

Aktivitas belajar mahasiswa mempengaruhi hasil belajar mahasiswa setelah pembelajaran. Belajar merupakan tindakan dan perilaku mahasiswa yang kompleks. Sebagai tindakan, maka belajar dialami oleh mahasiswa sendiri. Proses belajar tejadi berkat mahasiswa memperoleh sesuatu yang ada dilingkungan sekitar. Menurut Skinner yang dikutip Dimyati, (2006:9) belajar adalah suatu perilaku. Pada saat orang belajar, maka responsnya mejadi lebih

38 | Jurnal Kredo

Vol. 4 No. 1 Oktober 2020 baik. Sebaliknya, bila tidak belajar maka responsnya menurun.

Menurut Gagne yang dikutip Dimyati, (2006:10) belajar merupakan kegiatan yang kompleks. Hasil belajar merupakan kapabilitas. Setelah belajar orang memiliki keterampilan, pengetahuan sikap, dan nilai.

Pada umumnya hasil belajar meliputi pengetahuan, sikap dan keterampilan. Hasil belajar yang akan diperoleh siswa setelah menempuh pengalaman belajarnya atau proses belajar mengajar. Sudjana (2006:22) mengatakan hasil belajar adalah kemampuan-kemampuan yang dimiliki siswa setelah ia menerima pengalaman belajarnya.

Nasution (2010:17) menjelaskan pengertian hasil belajar adalah kesmepurnaan yang dicapai seseorang dalam berfikir, merasa dan berbuat. Hasil belajar dikatakan sempurna apabila seseorang memenuhi tiga aspek yakni kognitif, afektif dan psikomotor. Sebaliknya dikatakan kurang memuaskan jika seseorang belum mampu memenhi target dalam ketiga kriteria tersebut.

Thobroni (2011:22) mengatakan hasil belajar adalah pola-pola perbuatan, nilai-nilai, pengertian -pengertian, sikapsikap, apresiasi dan keterampilan. Djamarah (2008:45) mengatakan bahwa hasil belajar adalah prestasi dari suatu kegiatan yang telah dikerjakan, diciptakan, baik secara individu maupun kelompok. Hasil tidak akan pernah dihasilkan selama orang tidak melakukan sesuatu. Untuk menghasilkan sebuah prestasi dibutuhkan perjuangan dan pengorbanan yang sangat besar. Hanya dengan keuletan, sungguh- 


Kredo 4 (2020)
KREDO: Jurnal Ilmiah Bahasa dan Sastra
Terakreditasi Sinta 4 berdasarkan Keputusan Direktorat
Jenderal Penguatan Riset dan Pengembangan,
Kementerian Riset, Teknologi dan Pendidikan Tinggi
Republik Indonesia
Nomor: 23/E/KPT/2019. 08 Agustus 2019
https://jurnal.umk.ac.id/index.php/kredo/index

sungguh, kemauan yang tinggi dan rasa optimisme dirilah yang mampu mencapainya.

Hasil belajar seseorang sesuai dengan tingkat keberhasilan sesuatu dalam mempelajari materi pelajaran yang dinyatakan dalam bentuk nilai atau raport setiap bidang studi setelah mengalami proses belajar mengajar. Hasil belajar mahassiswa dapat diketahui setelah diaadakan evaluasi. Hasil dari evaluasi dapat memperlihatkan tentang tinggi atau rendahnya hasil belajar mahasiswa. Hasil belajar merupakan prestasi yang diperoleh setelah melakukan sesuatu kegiatan yang dimana akan menimbulkan suatu perubahan-perubahan pada diri individu.

\section{d. Keterampilan Berbicara}

Seluruh siswa dari pendidikan dasar sampai dengan perguruan tinggi wajib mempelajari dan memiliki empat keterampilan dasar dalam bahasa Inggris. Empat keterampilan tersebut adalah keterampilan membaca (reading skill), keterampilan berbicara (speaking skill), keterampilan menulis (writing skill), keterampilan menyimak (listening skill) (Tarigan, 2015:1). Kata keterampilan berasal dari kata terampil yang artinya adalah mampu, cekatan, atau cakap di dalam mengerjakan atau menyelesaikan suatu pekerjaan. Secara bahasa Keterampilan adalah suatu kemampuan dalam menuntaskan pekerjaan baik dan kemampuan untuk menggunakan bahasa lisan dan tulisan dengan baik dan benar. Kemudian, secara tematis keterampilan adalah kemampuan seorang pengguna bahasa untuk menjawab secara baik dan benar setiap rangsangan lisan atau tulisan, kemampuan untuk memahami penggunaan tata bahasa dan penggunaan atau pemilihan kosakata secara tepat, dan kemampuan untuk mengalihbahasakan dari satu bahasa ke bahasa yang lain.

Berbicara merupakan suatu aktivitas atau kegiatan kehidupan manusia yang sangat penting, karena dengan berbicara kita dapat berkomunikasi antar-sesama manusia, menyatakan pendapat, menyampaikan maksud dan pesan, mengungkapkan perasaan dalam segala kondisi emosional dan lain sebagainya. Dalam Kamus Besar Bahasa Indonesia (2002:148) menyatakan bahwa berbicara adalah berkata, bercakap, berbahasa; melahirkan pendapat dengan perkataan, tulisan dan sebagainya atau berunding.

Thornbury (2003:1) menyatakan bahwa berbicara adalah komunikasi secara oral. Berbicara adalah kemampuan untuk menggunakan bahasa untuk mengekspresikan perasaan, ide ide, dan pendapat sebagai komunikasi antara pembicara dan pendengar.

Tarigan (2015:14) juga menyatakan bahwa keterampilan berbicara adalah keterampilan mengucapkan bunyi-bunyi artikulasi atau mengucapkan kata-kata untuk mengekspresikan, menyatakan, menyampaikan pikiran, gagasan, perasaan terhadap pendengar. Pendengar menerima informasi melaui rangkaian nada, tekanan, dan penempatan persendian.

Berdasarkan pendapat di atas dapat disimpulkan bahwa berbicara adalah alat komunikasi secara oral dan merupakan keterampilan berbahasa seseorang yang melalui proses perkembangan kosa kata yang diperlukan bagi kegiatan berbicara yang 


Kredo 4 (2020)
KREDO: Jurnal Ilmiah Bahasa dan Sastra
Terakreditasi Sinta 4 berdasarkan Keputusan Direktorat
Jenderal Penguatan Riset dan Pengembangan,
Kementerian Riset, Teknologi dan Pendidikan Tinggi
Republik Indonesia
Nomor: 23/E/KPT/2019. 08 Agustus 2019
https://jurnal.umk.ac.id/index.php/kredo/index

Berbicara sebagai suatu cara berkomunikasi sangat berpengaruh dalam kehidupan kita. Dalam sistem inilah kita saling bertukar pendapat, gagasan, perasaan, dan keinginan, dengan bantuan lambang-lambang yang disebut kata-kata.

Berbicara memiliki tujuan untuk menginformasikan dan melaporkan, sesuatu hal pada pendengar. Sesuatu tersebut dapat berupa, menjelaskan sesuatu proses, menguraikan, menafsirkan, atau menginterpretasikan sesuatu hal, memberi, menyebarkan, atau menanamkan pengetahuan, menjelaskan kaitan, hubungan, relasi antara benda, hal, atau peristiwa.

Keterampilan berbicara seseorang bervariasi, mulai dari taraf baik atau lancar, sedang, gagap atau kurang. Kenyataan tersebut sebaiknya dijadikan landasan berbicara sebagai sarana komunikasi. Pengajaran berbicara pun harus berlandaskan konsep dasar berbicara sebagai sarana berkomunikasi.

Logan (2002:104-105) menerangkan bahwa konsep dasar berbicara sebagai sarana komunikasi mencakup sembilan hal, yakni:

a. Berbicara dan menyimak adalah suatu kegiatan resiprokal.

b. Berbicara adalah proses individu berkomunikasi.

c. Berbicara adalah ekspresi kreatif.

d. Berbicara adalah tingkah laku.

e. Berbicara adalah tingkah laku yang dipelajari.

f. Berbicara dipengaruhi kekayaan pengalaman.

g. Berbicara sarana memperluas cakrawala.

h. Kemampuan linguistik dan lingkungan berkaitan erat.

40 | Jurnal Kredo Vol. 4 No. 1 Oktober 2020 i. Berbicara adalah pancaran kepribadian.

Menurut Brook (dalam Tarigan, 1990:12) terdapat proses komunikasi yang harus dipahami dalam keterampilan berbahasa. Hal tersebut dapat dijelaskan sebagai berikut:

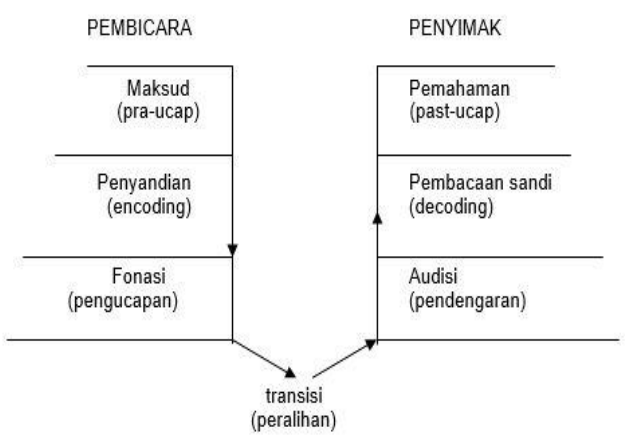

Gambar 1: Proses Komunikasi

Masih banyaknya mahasiswa yang mengalami kesulitan dalam berbicara bahasa Inggris ini dipengaruhi oleh beberapa faktor, diantaranya adalah proses pembelajaran.

\section{e. Model Pembelajaran Kooperatif}

Dalam proses pembelajaran dikenal beberapa istilah yang memiliki kemiripan makna, sehingga seringkali orang merasa bingung untuk membedakannya. Istilah-istilah tersebut adalah (1) pendekatan pembelajaran, (2) strategi pembelajaran, (3) metode pembelajaran, (4) teknik pembelajaran, (5) taktik pembelajaran, dan (6) model pembelajaran. Apabila antara pendekatan, strategi, metode, teknik dan bahkan taktik pembelajaran sudah terangkai menjadi satu kesatuan yang utuh maka terbentuklah model pembelajaran. Jadi, model pembelajaran pada dasarnya merupakan bentuk pembelajaran yang tergambar dari awal 


Kredo 4 (2020)
KREDO: Jurnal Ilmiah Bahasa dan Sastra
Terakreditasi Sinta 4 berdasarkan Keputusan Direktorat
Jenderal Penguatan Riset dan Pengembangan,
Kementerian Riset, Teknologi dan Pendidikan Tinggi
Republik Indonesia
Nomor: 23/E/KPT/2019. 08 Agustus 2019
https://jurnal.umk.ac.id/index.php/kredo/index

sampai akhir yang disajikan secara khas oleh pendidik.

Di era perkembangan dunia yang semakin maju dengan adanya ilmu teknologi yang semakin canggih, semua guru dari berbagai macam pelajaran harus mampu mengikuti perkembangan zaman dalam hal ini khususnya para pengajar bahasa Inggris. Pengajar tidak hanya menitikberatkan tugasnya hanya dengan mentransfer ilmu dan memberikan evaluasi kepada mahasiswa, tetapi Pengajar juga harus mampu menguasai teknologi dalam kegiatan belajar mengajarnya. Bahkan Pengajar sering lupa bahwa model atau teknik pengajaran sangatlah penting dan menjadi faktor utama dalam keberhasilan proses pengajaran.

Model pembelajaran mempunyai makna yang sangat luas dari sekedar metode, strategi, atau sebuah prosedur pembelajaran. Pada sekarang ini sudah banyak sekali dikembangkan berbagai macam model pembelajaran, mulai dari yang sangat sederhana sampai dengan model pembelajaran yang sangat rumit dan kompleks karena menggunakan banyak alat bantu dalam penerapannya. Contoh model pembelajaran yaitu antaranya model ceramah, demonstrasi, diskusi, bermain peran studi kasus, rally coach dan lain sebagainya. Tentunya setiap model pembelajaran mempunyai kelebihan dan kekurangan masingmasing.

Salah satu model pembelajaran yang digunakan dalam pembelajaran bahasa Inggris adalah Model Pembelajaran Kooperative. Model pembelajaran Kooperatif menurut Richards and Rodgers (2003:192) adalah, "an approach to teaching that makes maximum use of cooperative activities involving pairs and small groups of learners in the classroom". Dalam pembelajaran kooperatif mahasiswa beraktivitas secara berpasangan atau kelompok sehingga usaha pembelajaran berjalan maksimal.

Hal ini sejalan dengan yang dikatakan oleh Olsen and Kagan (1992:28):

"Cooperative learning is a group learning activity organized so that learning is dependent on the socially structured exchanged of information between learners in groups and in which each learner is held accountable for his or her own learning and is motivated to increase the learning of others."

Model pembelajaran kooperatif bukanlah sebuah metode, karena tidak ada tahapan di dalam pengajaran, hanya ada teori. Tujuan dari model pembelajaran kooperatif, yaitu:

1. Tujuan pengajar adalah menumbuhkan kemampuan penggunaan bahasa yang pernah dipelajarinya.

2. Tujuan pembelajar adalah memperoleh kemampuan penggunaan bahasa pada konteks dan situasi sebenarnya.

Kemudian, fokus model pembelajaran kooperatif adalah:

1. Fokus ke penggunaan bahasanya yang dipengaruhi oleh sosiolinguistik (penggunaan bahasa yang dihubungkan dengan lingkungan sosial).

2. Siswa tidak belajar tatabahasa, tetapi belajar penggunaan bahasanya agar dapat diterapkan dalam komunikasi. 


Kredo 4 (2020)
KREDO: Jurnal Ilmiah Bahasa dan Sastra
Terakreditasi Sinta 4 berdasarkan Keputusan Direktorat
Jenderal Penguatan Riset dan Pengembangan,
Kementerian Riset, Teknologi dan Pendidikan Tinggi
Republik Indonesia
Nomor: 23/E/KPT/2019. 08 Agustus 2019
https://jurnal.umk.ac.id/index.php/kredo/index

3. Pendidikan berpusat pada pembelajar (guru sebagai motivator), mengutamakan kegiatan latihan yang membiarkan pembelajar berpikir kreatif dan berpikir secara kritis sehingga kemampuan berbicara bahasa Inggris dapat lebih maksimal.

Pembelajaran kooperatif tidak sama dengan sekedar belajar dalam kelompok. Ada unsur pembelajaran kooperatif yang membedakan dengan pembelajaran kelompok yang dilakukan asal-asalan. Pelaksanaan prinsip dasar pokok sistem pembelajaran kooperatif dengan benar akan memungkinkan guru mengelola kelas dengan lebih efektif. Dalam pembelajaran kooperatif proses pembelajaran tidak harus belajar dari guru kepada siswa, siswa dapat saling bertukar informasi pembelajaran kepada siswa lainnya.

Pembelajaran oleh rekan sebaya (peer teaching) lebih efektif dari pada pembelajaran oleh guru. Pembelajaran kooperatifadalah teknik pengelompokan yang di dalamnya siswa bekerja terarah pada tujuan belajar bersama dalam kelompok kecil yang umumnya terdiri dari 4-5 orang.

Untuk mencapai hasil yang maksimal, terdapat lima unsur yang harus diterapkan dalam model pembelajaran kooperatif (Rusman, 2011: 212), yaitu:

1) Prinsip Ketergantungan Positif (Positive Interdependence), prinsip ini meyakini bahwa keberhasilan dalam menyelesaikan tugas tergantung pada usaha yang dilakukan oleh kelompok tersebut. Oleh karena itu, semua anggota kelompok akan merasakan saling ketergantungan.

42 | Jurnal Kredo Vol. 4 No. 1 Oktober 2020
2) Tanggung Jawab Perseorangan (Individual Accountability) keberhasilan kelompok sangat tergantung dari masing-masing anggota kelompoknya. Oleh karena itu, setiap anggota kelompok mempunyai tugas dan tanggung jawab dalam kelompok tersebut.

3) Interaksi Tatap Muka (Face To Face Promotive Interaction) dalam interaksi tatap muka siswa dalam kelompok berkesempatan untuk saling berdiskusi, saling memberi dan menerima informasi dari anggota kelompok lain. Kegiatan interaksi ini akan membentuk sinergi yang menguntungkan bagi semua anggota kelompok.

4) Partisipasi dan Komuniksi (Interpersonal Skill), komunikasi antar anggota kelompok atau keterampilan sosial merupakan prinsip kegiatan peserta didik untuk saling mengenal dan mempercayai, saling berkomunikasi secara akurat dan tidak ambisius, saling menerima dan saling mendukung, dan menyelesaikan konflik secara konstruktif. Kontribusi terhadap keberhasilan dalam pembelajaran kooperatif memerlukan ketarampilan interpersonal dalam kelompok kecil. Oleh karena itu, diperlukan keterampilan-keterampilan seperti kepemimpinan, pengambilan keputusan, membangun kepercayaan, berkomunikasi, dan mengelola konflik harus diajarkan dengan tepat sebagai keterampilan akademis.

5) Evaluasi Proses Kelompok (Group Processing) evaluasi proses kelompok merupakan kegiatan penilaian atau mengevaluasi proses 


Kredo 4 (2020)
KREDO: Jurnal Ilmiah Bahasa dan Sastra
Terakreditasi Sinta 4 berdasarkan Keputusan Direktorat
Jenderal Penguatan Riset dan Pengembangan,
Kementerian Riset, Teknologi dan Pendidikan Tinggi
Republik Indonesia
Nomor: 23/E/KPT/2019. 08 Agustus 2019
https://jurnal.umk.ac.id/index.php/kredo/index

kerja kelompok dan hasil kerja sama mereka, agar selanjutnya bisa bekerja sama dengan lebih efektif.

Pada pembelajaran kooperatif, para siswa saling membantu dalam menyumbangkan pikirannya. Menurut Kagan (2009:1.19) pembelajaran kooperatif adalah pengaturan pembelajaran serta mengacu pada kelompok kecil yang heterogen saling bekerja sama untuk mencapai tujuan bersama. Siswa bekerjasama untuk belajar dan bertanggung jawab dalam pembelajaran teman kelompok dan dirinya sendiri.

Unsur-unsur dasar dalam pembelajaran kooperatif Kagan (2009:12.2) dikenal dengan nama "PIES" dengan empat komponen yaitu interpendensi positif yang terjadi ketika keuntungan individu atau tim saling berhubungan. Komponen kedua, akuntabilitas individual terjadi saat siswa melakukan tugas kelompok. Komponen berikutnya terkait dengan partisipasi yang sama terhadap tanggung jawab dan masukan dari setiap anggota kelompok. Komponen terakhir, interaksi simultan terjadi ketika siswa dapat memanfaatkan waktu untuk berinteraksi dengan anggota kelompoknya. Keempat komponen tersebut hendaknya dapat terlaksana saat melaksanakan pembelajaran kooperatif.

Dari uraian di atas dapat disimpulkan bahwa pembelajaran kooperatif merupakan satu jenis pembelajaran aktif, dimana siswa belajar bersama dalam kelompok kecil untuk menyelesaikan tujuan secara bersamasama, melatih siswa untuk bekerjasama dalam menyelesaikan tugas. Pembelajaran kooperatif juga dapat merangsang siswa lebih semangat dalam belajar sehingga jika pembelajaran kooperatif ini diterapkan dalam penelitian, siswa dapat meningkatkan kemampuan berbicara bahasa Inggris nya dengan baik.

\section{f. Model Pembelajaran Rally Coach}

Salah satu strategi pembelajaran yang dapat digunakan dalam penelitian ini adalah dengan mengimplementasikan model pembelajaran Rally Coach. Rally coach merupakan salah satu strategi pembelajaran kooperatif (cooperative learning) yang sangat tepat untuk diimplementasikan dalam pelajaran bahasa Inggris khususnya keterampilan berbicara. Strategi ini mendorong mahasiswa untuk saling membantu satu dengan yang lain dalam menjawab pertanyaan, siswa diharuskan untuk saling berkomunikasi dan memperhatikan dengan teliti proses yang dilakukan ketika sedang menjawab pertanyaan. Ketika siswa sedang menjawab persoalan, tidak lain membutuhkan proses berpikir yang sedemikian rupa sehingga dapat dituangkan dalam tulisan dan kemudian dikomunikasikan kepada orang lain.

Model pembelajaran Rally Coach merupakan bagian model pembelajaran cooperative learning. Hal ini dikarenakan kelompok strategi mengajar ini memberikan peran terstruktur bagi siswa sambil menekankan interaksi antarsiswa (Eggen dkk., 2012:171). Pendapat tersebut sejalan dengan Slavin (2005:11) yang mengungkapkan bahwa pembelajaran kooperatif dapat menyumbangkan ide siswa berkerja sama dalam belajar dan bertanggung jawab terhadap teman satu timnya sehingga mampu membuat diri mereka 


Kredo 4 (2020)
KREDO: Jurnal Ilmiah Bahasa dan Sastra
Terakreditasi Sinta 4 berdasarkan Keputusan Direktorat
Jenderal Penguatan Riset dan Pengembangan,
Kementerian Riset, Teknologi dan Pendidikan Tinggi
Republik Indonesia
Nomor: 23/E/KPT/2019. 08 Agustus 2019
https://jurnal.umk.ac.id/index.php/kredo/index

belajar sama baiknya. Hal ini menunjukkan bahwa model pembelajaran Rally Coach menekankan interaksi antarsiswa dengan tujuan agar mereka dapat belajar dengan baik bersama-sama.

Model pembelajaran Rally coach adalah model pembelajaran yang melibatkan dua orang atau partner yang saling membantu dalam satu kelompok yang mempunyai kemampuan yang berbeda. Dalam model pembelajaran Rally Coach masing-masing pasangan bergantian untuk memecahkan suatu kasus atau masalah yang diberikan oleh pengajar. Kasus atau masalah yang diberikan oleh pengajar dalam pembelajaran kooperatif Rally Coach menggunakan lembar kerja baik tertulis maupun lisan. Ketrampilan sosial (social skill), ketrampilan komunikasi (communication skill), membangun pengetahuan (knowledge building), proses belajar (procedure learning), dan ketrampilan berpikir (thinking skill) dapat dikembangkan dalam model pembelajaran ini.

Sintak dalam model pembelajaran cooperative Rally Coach adalah:

1. Partner A memecahkan masalah,

2. Partner B Memerhatikan dan mendengarkan, mengoreksi jika diperlukan memberikan komentar jika jawaban partner A benar maka partner B memberikan pujian

3. Partner B memecahkan masalah selanjutnya,

4. Partner A memerhatikan dan mendengarkan, mengoreksi, jikia diperlukan membeerikan tanggapan dan jika jawaban partbner $\mathrm{B}$ benar maka partner memberikan pujian.
Kedua pasangan mengulangi bergantian memecahkan masalah berturut-turut (Kagan, 2009:632).

Jadi yang dimaksud sebagai pembelajaran kooperatif model Rally Coach adalah pembelajaran yang dilakukan di kelas untuk memaksimalkan hasil belajar mahasiswa dengan memasangkan mahasiswa berdua atau berkelompok.

Model Rally Coach dapat dipilih dalam pembelajaran keterampilan berbicara karena mahasiswa akan lebih termotivasi dalam pembelajaran sehingga tujuan pembelajaran dapat tercapai secara optimal. Pada saat mahasiswa berbicara dengan petunjuk dari teman sehingga akan merangsang siswa dalam memahami konsep dengan baik serta pembelajaran dalam suasana yang lebih menyenangkan.

Pada proses pembelajaran model Rally Coach ini, siswa mendapat manfaat langsung untuk belajar mencurahkan kreativitasnya dalam mengembangkan keterampilan berbicara, memahami sudut pandang orang lain, meningkatkan kemampuan pemecahan masalah dan memberikan umpan balik (Eggen, 2012:130-131). Dengan demikian, proses pembelajaran ini membantu orang lain, belajar untuk menghargai orang lain, dan belajar untuk menerima kritik konstruktif.

\section{METODE PENELITIAN}

Penelitian ini menggunakan model eksperimen, yaitu penelitian yang dengan sengaja mengusahakan timbulnya variabel- variabel dan selanjutnya dikontrol untuk dilihat 


Kredo 4 (2020)
KREDO: Jurnal Ilmiah Bahasa dan Sastra
Terakreditasi Sinta 4 berdasarkan Keputusan Direktorat
Jenderal Penguatan Riset dan Pengembangan,
Kementerian Riset, Teknologi dan Pendidikan Tinggi
Republik Indonesia
Nomor: 23/E/KPT/2019. 08 Agustus 2019
https://jurnal.umk.ac.id/index.php/kredo/index

pengaruhnya terhadap hasil belajar (Arikunto, 2004: 86).

Penelitian ini dilaksanakan di STMIK Pranata Indonesia pada semester ganjil tahun ajaran 2018/2019.

Selanjutnya untuk mengetahui ada tidaknya pengaruh hasil eksperimental berupa perlakuan model pembelajaran yaitu model pembelajaran Rally Coach pada kemampuan berbicara Bahasa Inggris, maka peneliti mengadakan tes atau evaluasi hasil belajar pada masingmasing kelas sampel setelah eksperimen dilakukan.

Subjek penelitian dipilih secara acak dengan membuat dua kelompok, kelompok eksperimen dan kelompok kontrol. Dalam penelitian ini diperoleh mahasiswa sejumlah 80 orang yang dipilih secara acak. Kelompok A (X1) untuk kelas yang akan menggunakan teknik Rally Coach dalam pembelajaran sejumlah 40 mahasiswa (kelas eksperimen), dan kelompok B (X2) untuk kelas yang akan menggunakan teknik konvensional dalam pembelajaran sejumlah 40 mahasiswa (kelas kontrol).

Masing-masing kelompok diberi perlakuan (treatament) yang berbeda, kelompok eksperimen diberikan materi dengan menggunakan model pembelajaran Rally Coach dan kelompok kontrol diberikan materi dengan menggunakan model ceramah. Masing-masing kelompok tidak diberikan pretest (tes awal) untuk melihat keadaan awal, tetapi diberikan post test (tes akhir) untuk melihat apakah ada perbedaan setelah diberi perlakuan. Hasil post test kedua kelompok dibandingkan untuk melihat ada tidaknya perubahan atau peningkatan keterampilan berbicara Bahasa Inggris setelah pemberian treatment model pembelajaran Rally Coach. Desain penelitian yang dipakai pada penelitian ini adalah sebagai berikut:

\begin{tabular}{|c|c|}
\hline $\mathrm{A}$ & $\mathrm{B}$ \\
\hline $\mathrm{X} 1$ & $\mathrm{X} 2$ \\
\hline
\end{tabular}

Gambar 1 Desain Penelitian

Keterangan:

$\mathrm{A}=$ Siswa kelas teknik Rally Coach

$\mathrm{B}=$ Siswa kelas teknik Konvensional

$\mathrm{X}_{1}=$ Nilai hasil belajar kelas Rally

Coach

$\mathrm{X}_{2}=$ Nilai hasil belajar kelas

Konvensional

Sumber data dalam penelitian ini adalah hasil tes keterampilan berbicara mahasiswa dalam pembelajaran bahasa Inggris yang diajarkan dengan teknik Konvensional dan teknik Rally Coach.

Adapun tes yang diujikan berupa tes lisan pada mahasiswa dari kelas eksperimen yang menggunakan model Rally Coach dan juga pada mahasiswa dari kelas control yang menggunakan teknik konvensional.

Dalam penilaian keterampilan berbicara terdapat 5 aspek yang digunakan, yaitu Grammar (tata bahasa), Vocabulary (kosakata), Comprehension (pemahaman), Fluency (kelancaran), dan Pronunciation (pelafalan) (Brown, 2010).

Hasil yang berasal dari tes kedua kelas tersebut akan dijadikan sumber data dalam penghitungan statistik pada hasil dan pembahasan. 


\begin{tabular}{|c|c|c|} 
Kredo 4 (2020) \\
KREDO: Jurnal Ilmiah Bahasa dan Sastra \\
Terakreditasi Sinta 4 berdasarkan Keputusan Direktorat \\
Jenderal Penguatan Riset dan Pengembangan, \\
Kementerian Riset, Teknologi dan Pendidikan Tinggi \\
Republik Indonesia \\
Nomor: 23/E/KPT/2019. 08 Agustus 2019 \\
https://jurnal.umk.ac.id/index.php/kredo/index
\end{tabular}

\section{HASIL DAN PEMBAHASAN}

Hasil dan pembahasan dalam penelitian ini akan menyajikan data dari hasil tes keterampilan berbicara bahasa Inggris baik kelas eksperimen dan kelas kontrol. Berikut data hasil tes dari masing-masing kelas:

Hasil keterampilan berbicara bahasa Inggris kelas kontrol dapat dilihat pada tabel distribusi frekuensi berikut:

Tabel 1 Tabel Distribusi Frekuensi Kelas Kontrol

\begin{tabular}{cccccc}
\hline Skor & $\mathbf{f}$ & $\mathbf{X i}$ & $\mathbf{f . X i}$ & $\mathbf{X i}^{\mathbf{2}}$ & $\mathbf{f . X i}^{\mathbf{2}}$ \\
\hline $38-45$ & 7 & 41,5 & 290,5 & 1722,25 & 12055,8 \\
\hline $46-53$ & 3 & 49,5 & 148,5 & 2450,25 & 7350,75 \\
\hline $54-61$ & 10 & 57,5 & 575 & 3306,25 & 33062,5 \\
\hline $62-69$ & 3 & 65,5 & 196,5 & 4290,25 & 12870,8 \\
\hline $70-77$ & 5 & 73,5 & 367,5 & 5402,25 & 27011,3 \\
\hline $78-85$ & 8 & 81,5 & 652 & 6642,25 & 53138 \\
\hline $86-93$ & 4 & 89,5 & 358 & 8010,25 & 32041 \\
\hdashline$\sum$ & $\mathbf{4 0}$ & & $\mathbf{2 5 8 8}$ & & $\mathbf{1 7 7 5 3 0}$ \\
\hline
\end{tabular}

Dari tabel tersebut terlihat bahwa masih terdapat 7 mahasiswa yang mendapat skor terendah, dengan nilai antara 38 sampai dengan 45. Jumlah terbanyak dengan 10 mahasiswa dengan nilai antara 54-61. Hal ini menunjukkan bahwa penguasaan keterampilan berbicara mahasiswa masih rendah.

Berdasarkan hasil perhitungan, diperoleh bahwa keterampilan berbicara Bahasa Inggris pada kelompok kelas kontrol, dari 40 mahasiswa responden diperoleh rata-rata nilai tes sebesar 64,7. Untuk nilai median diperoleh nilai 61,5 , untuk nilai modus diperoleh nilai 57,5, untuk nilai varians diperoleh nilai 258,6256. Dan dengan simpangan baku 16,082 .

Dari hasil yang diperoleh tersebut, dapat disimpulkan bahwa rata-rata yang diperoleh oleh mahasiswa tanpa penggunaan model pembelajaran Rally Coach masih rendah.

46 | Jurnal Kredo

Vol. 4 No. 1 Oktober 2020
Sebaran data hasil keterampilan berbicara mahasiswa kelas kontrol dapat dilihat pada grafik berikut:

Grafik I Hasil Keterampilan Berbicara Kelas Kontrol

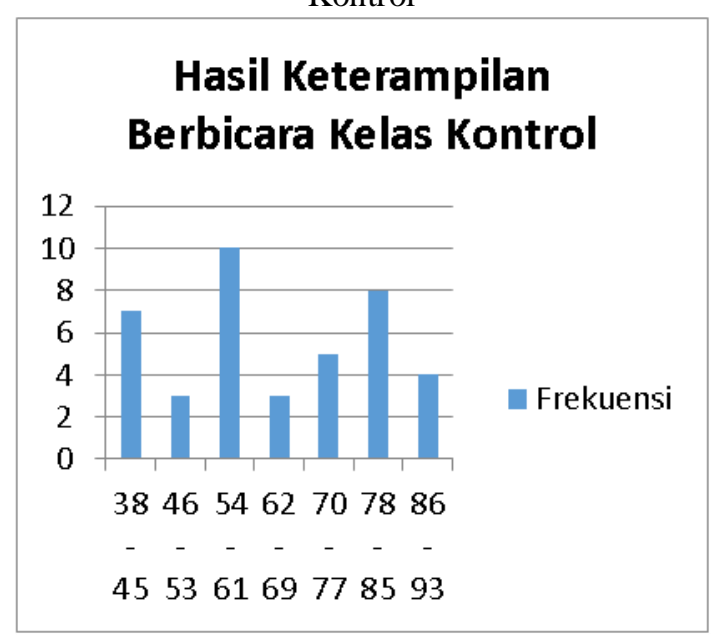

Kemudian, untuk hasil keterampilan berbicara bahasa Inggris kelas eksperimen dapat dilihat dari tabel distribusi frekuensi berikut:

Tabel 2 Tabel Distribusi Frekuensi Kelas Eksperimen

\begin{tabular}{cccccc}
\hline Skor & $\mathbf{f}$ & $\mathbf{X i}$ & $\mathbf{f . X i}$ & $\mathbf{X i}^{\mathbf{2}}$ & $\mathbf{f . X \mathbf { X i } ^ { \mathbf { 2 } }}$ \\
\hline $42-49$ & 6 & 45,5 & 273 & 2070,25 & 12421,5 \\
\hdashline $50-57$ & 2 & 53,5 & 107 & 2862,25 & 5724,5 \\
\hdashline $58-65$ & 7 & 61,5 & 430,5 & 3782,25 & 26475,75 \\
\hdashline $66-73$ & 7 & 69,5 & 486,5 & 4830,25 & 33811,75 \\
\hdashline $74-81$ & 5 & 77,5 & 387,5 & 6006,25 & 30031,25 \\
\hdashline $82-89$ & 9 & 85,5 & 769,5 & 7310,25 & 65792,25 \\
\hdashline $90-97$ & 4 & 91,5 & 366 & 8372,25 & 33489 \\
\hdashline$\sum$ & $\mathbf{4 0}$ & & $\mathbf{2 8 2 0}$ & & $\mathbf{2 0 7 7 4 6}$
\end{tabular}

Dari tabel tersebut terlihat bahwa terdapat peningkatan dimana hanya 6 mahasiswa yang mendapat skor terendah yaitu antara 42 sampai dengan 49. Jumlah terbanyak dengan 9 mahasiswa memperoleh skor antara 82-89. Maka dapat disimpulkan bahwa terdapat 


\begin{tabular}{|c|c|c|} 
Kredo 4 (2020) \\
KREDO: Jurnal Ilmiah Bahasa dan Sastra \\
Terakreditasi Sinta 4 berdasarkan Keputusan Direktorat \\
Jenderal Penguatan Riset dan Pengembangan, \\
Kementerian Riset, Teknologi dan Pendidikan Tinggi \\
Republik Indonesia \\
Nomor: 23/E/KPT/2019. 08 Agustus 2019 \\
https://jurnal.umk.ac.id/index.php/kredo/index
\end{tabular}

perbedaan nilai atau peningkatan. Peningkatan ini dapat terlihat jelas pada skor terendah masing-masing kelompok kelas, dimana kelas eksperimen memiliki skor terendah 42 sedangkan kelas kontrol memiliki skor terendah 38 .

Berdasarkan hasil perhitungan, diperoleh bahwa keterampilan berbicara Bahasa Inggris pada kelompok kelas eksperimen diperoleh rata-rata nilai 70,5. Untuk nilai median diperoleh nilai 85,056 . Untuk nilai varians diperoleh nilai 229,128 . Dan, nilai simpangan baku 15,14 .

Dari hasil tersebut, dapat disimpulkan bahwa nilai mahasiswa cukup baik dengan adanya penggunaan model pembelajaran Rally Coach.

Sebaran data hasil keterampilan berbicara mahasiswa kelas eksperimen dapat dilihat pada grafik berikut:

Grafik II Hasil Keterampilan Berbicara Kelas Eksperimen

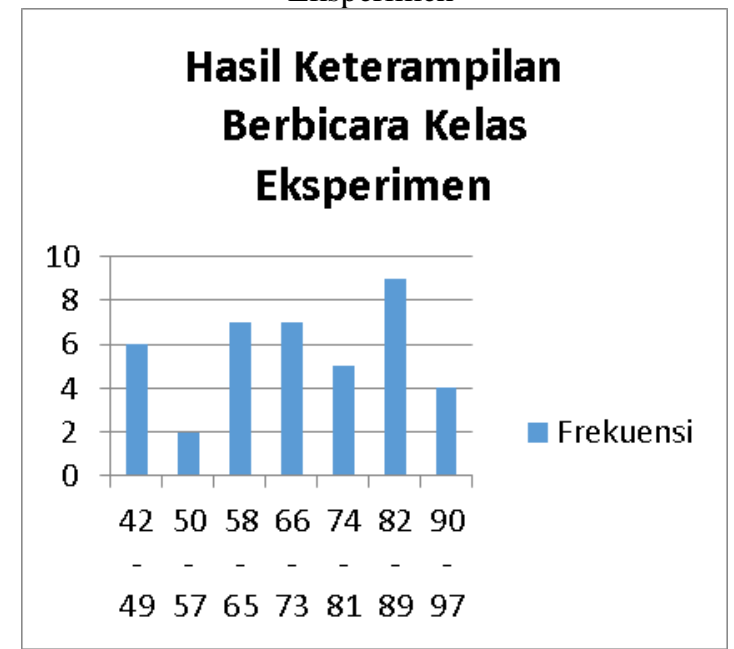

Berdasarkan pada hasil perhitungan tersebut, dapat dilihat bahwa terdapat perbedaan hasil belajar keterampilan berbicara bahasa Inggris antara kelas eksperimen dan kelas kontrol. Hasil belajar keterampilan berbicara bahasa Inggris kelas eksperimen menunjukkan nilai yang lebih tinggi dari hasil keterampilan berbicara bahasa Inggris kelas kontrol. Maka dapat disimpulkan bahwa model pembelajaran Rally Coach dapat meningkatkan hasil belajar keterampilan berbicara bahasa Inggris mahasiswa. Hal ini terjadi karena model pembelajaran Rally Coach melibatkan dua orang atau partner yang sangat membantu siswa. Adanya partner membuat mereka lebih nyaman dan termotivasi dalam berbicara karena peran teman/partner yang mampu memperhatikan dan mengoreksi setiap kalimat atau komentar yang akan disampaikan.

Selanjutnya, data yang diperoleh harus melalui proses analisis persyaratan data. Analisis yang digunakan dalam tahap ini adalah uji normalitas dan uji homogenitas.

Uji normalitas pada penelitian ini adalah uji normalitas parametrik dengan menggunakan uji liliefors. Uji normalitas dilakukan untuk mengetahui apakah data populasi berdistribusi normal atau tidak berdasarkan data yang diperoleh.

Hasil dari uji Normalitas dapat dilihat dari tabel berikut:

\begin{tabular}{cccccc} 
& \multicolumn{4}{c}{ Tabel 3 Uji Normalitas } \\
\hline NO & Data & \multicolumn{2}{c}{ Lo hitung } & Lo tabel & Keterangan \\
1 & Y1 & 0,09 & 0,140 & Normal & \\
2 & Y2 & 0,0915 & 0,140 & Normal & \\
\hline
\end{tabular}

Berdasarkan tabel tersebut diatas, tampak bahwa Lo hitung < Lo tabel, maka masing-masing kelompok memiliki data yang normal.

Kemudian, dilakukan uji homogenitas pada data. Uji homogenitas 


Kredo 4 (2020)
KREDO: Jurnal Ilmiah Bahasa dan Sastra
Terakreditasi Sinta 4 berdasarkan Keputusan Direktorat
Jenderal Penguatan Riset dan Pengembangan,
Kementerian Riset, Teknologi dan Pendidikan Tinggi
Republik Indonesia
Nomor: 23/E/KPT/2019. 08 Agustus 2019
https://jurnal.umk.ac.id/index.php/kredo/index

dilakukan untuk menguji apakah terdapat kesamaan (homogen) atau ketidaksamaan varians populasi. Apabila ada kesamaan varians, maka dapat dikatakan bahwa populasi tersebut berasal dari varians yang homogen atau sebaliknya. Pengujian homogenitas dilakukan dengan uji fisher $(\mathrm{F})$.

Dari hasil perhitungan uji homogenitas, didapat hasil bahwa nilai $\mathbf{F}_{\text {hitung }}$ 1,13 $<\mathbf{F}_{\text {tabel }}$ 1,69. Maka, dapat disimpulkan bahwa kelompok data bersifat homogen.

Hasil pengujian hipotesis menunjukkan hasil $\mathbf{t}_{\text {hitung }}>\mathbf{t}_{\text {tabel }} ; \mathbf{1 , 6 9}>$ 1,667 yang berarti hasil uji hipotesis positif dan signifikan.

Sehingga, bisa ditarik kesimpulan terdapat pengaruh yang signifikan dan positif penggunaan teknik Rally Coach terhadap keterampilan berbicara bahasa Inggris mahasiswa STMIK Pranata Indonesia, Cileungsi.

\section{SIMPULAN}

Berdasarkan hasil penelitian, maka penulis dapat menarik beberapa kesimpulan:

1. Nilai rata-rata nilai keterampilan berbicara bahasa Inggris 40 mahasiswa pada kelompok kelas kontrol diperoleh nilai tes sebesar 64,7. Untuk nilai median diperoleh nilai 61,5, untuk nilai modus diperoleh nilai 57,5 , untuk nilai varians diperoleh nilai 258,6256. Dan dengan simpangan baku 16,082. Dan untuk nilai rata-rata keterampilan berbicara bahasa Inggris 40 mahasiswa kelas eksperimen adalah sebesar 70,5. Nilai median sebesar 71,21 . Nilai modus sebesar 85,06.
Untuk nilai median diperoleh nilai 85,056 . Untuk nilai varians diperoleh nilai 229,128 . Dan dengan simpangan baku 15,14. Dengan data tersebut terlihat jelas bahwa terdapat perbedaan hasil antara kelas eksperimen dan kelas kontrol, dimana nilai kelas eksperimen lebih tinggi dari kelas kontrol

2. Dalam uji normalitas, diperoleh Lo hitung kelas kontrol 0,09 dan Lo hitung pada kelompok kelas eksperimen 0,0915. Sedangkan, diketahui Lo tabel 0,140. Karena, nilai Lo hitung kelas kontrol $(0,09)$ dan kelas eksperimen $(0,0915)$ lebih kecil dari nilai Lo tabel $(0,140)$, maka masing-masing kelompok data berdistribusi normal. Dan, dalam uji homogenitas, diperoleh hasil $F_{\text {hitung }}$ 1,13. Sedangkan $F_{\text {tabel }}$ sebesar 1,69. Maka dapat disimpulkan bahwa data homogen, karena $F_{\text {hitung }}$ lebih kecil dari $\mathrm{F}_{\text {tabel. }}$

3. Dalam perhitungan uji hipotesis dengan menggunakan uji-t, diperoleh nilai $t_{\text {hitung }}$ sebesar 1,69. Dan nilai $t_{\text {tabel }}$ untuk $\alpha=0,05$ dan $\mathrm{dk}=78$ yaitu 1,667. Karena nilai thitung lebih besar dari $t_{\text {tabel }}(1,69>1,667)$.

Maka berdasarkan hasil tersebut, dapat disimpulkan bahwa terdapat pengaruh yang positif dan signifikan penggunaan model pembelajaran Rally Coach terhadap keterampilan berbicara bahasa Inggris Mahasiswa STMIK Pranata, Cileungsi.

Dengan adanya penggunaan model pembelajaran Rally Coach, mahasiswa lebih percaya diri dan aktif dalam proses pembelajaran bahasa Inggris khususnya keterampilan berbicara. Penggunaan model yang melibatkan interaksi grup 


\begin{tabular}{|c|c|c|} 
Kredo 4 (2020) \\
KREDO: Jurnal Ilmiah Bahasa dan Sastra \\
Terakreditasi Sinta 4 berdasarkan Keputusan Direktorat \\
Jenderal Penguatan Riset dan Pengembangan, \\
Kementerian Riset, Teknologi dan Pendidikan Tinggi \\
Republik Indonesia \\
Nomor: 23/E/KPT/2019. 08 Agustus 2019 \\
https://jurnal.umk.ac.id/index.php/kredo/index
\end{tabular}

atau pasangan membuat mahasiswa lebih mudah, lebih berani, dan percaya diri dalam berbicara.

Kemudian, berdasarkan pada hasil tersebut, peneliti dapat memberikan saran:

1. Penggunaan model pembelajaran seperti teknik Rally Coach seharusnya lebih ditingkatkan lagi, dengan penggunaan teknik Rally Coach yang intens akan berpengaruh pada peningkatan kemampuan atau keterampilan berbicara Bahasa Inggris.

2. Pengajar harus dapat berkreasi dalam menggunakan metode pembelajaran yang bervariasi agar mahasiswa tidak cepat bosan dalam pembelajaran Bahasa Inggris dikelas. Dengan suasana kelas yang menyenangkan akan membuat mahasiswa dengan mudah dan cepat menguasai keterampilan berbicara Bahasa Inggris.

3. Untuk menjaga suasana kelas menjadi hidup dan menarik, harus terjalin komunikasi yang baik antara pengajar dan mahasiswa. Dengan komunikasi yang baik membuat tujuan dari belajar akan dengan mudah tercapai.

\section{DAFTAR PUSTAKA}

A.S. Hornby. 2006. Oxford Advanced Learner's Dictionary. Oxford: Oxford University Press.

Arikunto. 2004. Dasar-Dasar Evaluasi Pendidikan. Jakarta: Bumi Aksara.

Boediono. 2003. Standar Kompetensi Mata Pelajaran Bahasa Inggris SMP dan MTs. Jakarta: Departemen Pendidikan Nasional.

Brown H, Doughlas. 2010. Language Assessment: Principles and Classroom Abilities. New York: Longman.

Celce-Murcia, Ms Olshtain, E. 2001, Discourse \& Context in Language Teaching A Guide for Language Teachers. London: Cambridge University Press

Dimyati dan Mudjiono. 2006. Belajar dan Pembelajaran. Jakarta: PT Rineka Cipta

Djamarah, Syaiful Bahri. 2008. Strategi Belajar Mengajar. Jakarta: PT. Rineka Cipta.

Eggen, P. dan Kauchak, D. (2012). Strategies and Models for Teachers Teaching Content and Thinking Skill. Boston: Pearson Education Inc.

Farikah. (2016). Implementasi Model Child Friendly School (CFS) dalam Pembelajaran Bahasa Inggris (Studi Kasus di SD Negeri Secang 1 Kabupaten Magelang). In 


Kredo 4 (2020)
KREDO: Jurnal Ilmiah Bahasa dan Sastra
Terakreditasi Sinta 4 berdasarkan Keputusan Direktorat
Jenderal Penguatan Riset dan Pengembangan,
Kementerian Riset, Teknologi dan Pendidikan Tinggi
Republik Indonesia
Nomor: 23/E/KPT/2019. 08 Agustus 2019
https://jurnal.umk.ac.id/index.php/kredo/index

Prosiding Seminar Nasional "Optimalisasi Peran Pendidikan dalam Membangun Karakter Anak untuk Menyongsong Generasi Emas Indonesia” (pp. 546-549). Universitas Ahmad Dahlan.

Kagan, S. 2009. Kagan Cooperative Learning. Kagan Publishing.

Logan dkk., 2002. Argumentasi dan Narasi. Jakarta: PT Gramedia.

Maulidiyah, Hidayatul. 2014. Bahasa Inggris untuk Taman Kanak Kanak: Silabus, Panduan untuk Guru beserta Materi Instruksional dalam CD. Malang.

Mckay, Sandra Lee dan Nancy H. Hornberger. 2009. Sociolinguistics and Language Teaching. London: Cambridge University Press.

Nasution, S. 2010. Berbagai Pendekatan dalam Proses Belajar dan Mengajar. Jakarta: Bumi Aksara.

Nurroeni, C. 2013. Keefektifan Model Mind Mapping terhadap Aktifitas dan Hasil Belajar IPA. Journal of Elementary Education. Volume 2 Nomor 1 Tahun 2013.

Olsen, R and S. Kagan. 1992. Cooperative Language Learning: A Teacher's Resource Book. New York: Prentice Hall.

Permana, Rakmad Hidayatullah. 2019. Survei Kualitas Pendidikan PISA 2018: RI Sepuluh Besar dari Bawah. detikNews: (http://m.detik.com).

Poerwodarminto, W.J.S. 2004. Kamus Besar Bahasa Indonesia. Jakarta: Balai Pustaka

Rachmawati, Umi dan Suwarsih Madya. 2014. Pengembangan Webquest Sebagai Media Instruksional Membaca Siswa SMA Negeri 1 Muntilan. Jurnal Kependidikan. Volume 44, Nomor 1.

Ricards, Jack C. and Theodore S. Rodgers. 2003. Approaches and Methods in Languange Teaching. Cambrige University Press.

Ricards, Jack C. and Willy A. Renandya. 2002. Methodology in Language Teaching: An Anthology of Current Practice. United States of America: Cambrige University Press.

Rusman. (2011). Model-Model Pembelajaran Mengembangkan Profesionalisme Guru. Jakarta: PT. Raja Grafindo Persada.

Siahaan, Sanggam. 2008. Issues in Linguistics. Yogyakarta: Graha Ilmu.

50 | Jurnal Kredo

Vol. 4 No. 1 Oktober 2020 


Kredo 4 (2020)
KREDO: Jurnal Ilmiah Bahasa dan Sastra
Terakreditasi Sinta 4 berdasarkan Keputusan Direktorat
Jenderal Penguatan Riset dan Pengembangan,
Kementerian Riset, Teknologi dan Pendidikan Tinggi
Republik Indonesia
Nomor: 23/E/KPT/2019. 08 Agustus 2019
https://jurnal.umk.ac.id/index.php/kredo/index

Slavin, R. (2005). Cooperative Learning. London: Allymand Bacon.

Sudjana, N. 2009. Penilaian Hasil Proses Belajar Mengajar. Bandung: Remaja Rosdakarya

Suharwati, S.I., Sumarmi. I Nyoman Ruja. 2016. Pengaruh Model Pembelajaran Resource Based Leraning Terhadap minat dan Hasil Belajar Geografi Siswa SMA. Jurnal Pendidikan: Teori, Penelitian, dan Pengembangan. Volume 1 Nomor 3 Tahun 2016.

Tarigan, Henry Guntur. 1990.Berbicara Sebagai Suatu Keterampilan Berbahasa; Cetakan ke-6. Bandung: Angkasa.

Tarigan, Henry Guntur. 2008. Berbicara: Sebagai Suatu Keterampilan Berbahasa. Bandung: Angkasa.

Tarigan, Henry Guntur. 2015. Berbicara Sebagai Suatu Keterampilan Berbahasa. Bandung: Angkasa.

Thobroni, Muhammad dan Mustofa, Arif. 2011. Belajar \& Pembelajaran : Pengembangan Wacana dan Praktik Pembelajaran dalam Pembangunan Nasional. Jogjakarta : Ar-Ruzz Media.

Thornbury, Scott. 2002. How to Teach Speaking. New York: Longman.

Wardah. 2017. Pembelajaran Bahasa Inggris di Perguruan Tinggi Islam dalam Konteks ESP (English for Spesific Purposes). Pontianak: Jurnal Al-Hikmah. 